\title{
Sydney Olympic Millennium Parklands Methods
}

\section{Firm Liaisons:}

Kay Cheng

Director of Business Development

PWP Landscape Architecture

Sarah Kuehl

Partner

PWP Landscape Architecture

This case study was produced in 2010 as part of the Landscape Architecture Foundation's Landscape Performance Series pilot. Firms submitted their projects, and LAF staff worked with firm representatives to document the project and its environmental, social, and economic benefits.

To cite:

Landscape Architecture Foundation. "Sydney Olympic Millennium Parklands Methods." Landscape Performance Series. Landscape Architecture Foundation, 2010.

https://doi.org/10.31353/cs1441

The full case study can be found at:

https://landscapeperformance.org/case-study-briefs/sydney-olympic-millennium-parklands 


\section{Sydney Olympic Millennium Parklands Methodology for Landscape Performance Benefits}

- Restored and protected more than 15 miles of continuous waterfront along the Parramatta River and Homebush Bay, including a 124-acre Aboriginal forest.

Figures from plan and construction documents.

- Treats contaminated soils. Roughly 35 megaliters of leachate have been collected and transferred to a waste treatment facility. Groundwater contaminated with $750 \mathrm{~kg}$ of hydrocarbons, including $430 \mathrm{~kg}$ of benzene, has been successfully degraded by microorganisms in the Wilson Park bioremediation ponds.

Figures from page 10 of "Millennium Parklands 10 Years On: A Performance Review of the 1997 Concept Plan and Aspects of its Implementation".

- Recycled over 4,600 megaliters of water over 7 years, providing irrigation and greywater on-site use. Of total water consumption during this period, only $2 \%$ was sourced from Sydney's water supply despite one of the worst droughts in Australia's history.

Figures from page 10 and page 14 of "Millennium Parklands 10 Years On: A Performance Review of the 1997 Concept Plan and Aspects of its Implementation" prepared by HASSELL in consultation with Fathom Consulting and the Sydney Olympic Park Authority in October 2008.

- Provides habitat for more than 180 native species of birds, including those in decline in other areas. The once-endangered Green and Golden Bell Frog population in the parklands is now one of the largest populations in New South Wales.

Figures from page 13 of "Millennium Parklands 10 Years On: A Performance Review of the 1997 Concept Plan and Aspects of its Implementation".

- Provides venues for a variety of recreation and leisure pursuits for 2.5 million people annually. Visitation grew from 750,000 in 2002 to 2.3 million in 2007.

Figures from page 10-11 of "Millennium Parklands 10 Years On: A Performance Review of the 1997 Concept Plan and Aspects of its Implementation".

- Provides educational opportunities for nearly 20,000 children annually, with 18,600 students participating in curriculum-based environmental education programs in the parklands in 2006-07.

Figures from page 10 of "Millennium Parklands 10 Years On: A Performance Review of the 1997 Concept Plan and Aspects of its Implementation". 